\title{
MODEL PROBLEM POSING UNTUK MENINGKATKAN KUALITAS PEMBELAJARAN BAHASA INGGRIS DI PRODI DESAIN INTERIOR TAHUN 2018
}

\author{
Etty Ekowati \\ Jurusan Desain, Fakultas Seni Rupa dan Desain \\ Institut Seni Indonesia (ISI) Surakarta \\ etty@isi-ska.ac.id
}

\begin{abstract}
Classroom Action Research (CAR) is a way for lecturers to improve and evaluate classroom learning. With CAR, lecturers can find out problems in the teaching and learning process in the classroom. English course is a subject that must be taken by design students. To overcome the problems in learning English the problem posing model is used. Problem posing, namely problem solving through elaboration, which is to reformulate the problem into parts that are simpler so that it is understood. The syntax is: understanding, solutions, identifying errors, minimizing writing counts, looking for alternatives, compiling questions. The formulation of the problem in this research is how the technique of applying English subject learning with the probem posing model in Interior Design Study Program students at ISI Surakarta and whether the application of the problem posing learning model through English subjects can improve verbal skills in Interior Design Study Program students at ISI Surakarta. The research objectives in this study are to describe the application techniques of learning English courses with probem posing models in Interior Design Study Program students at ISI Surakarta and explain the application of problem posing learning models through English subjects that can improve verbal skills in Interior Design Study Program students at ISI Surakarta This type of research is classroom action research. The results of this study are to find techniques for applying English learning courses with the probem posing model in Interior Design Study Program students at ISI Surakarta and explain the application of the probem posing learning models through English courses that can improve verbal abilities in Interior Design Study Program students at ISI Surakarta.
\end{abstract}

Keywords: CAR, Problem posing, evaluation, model

\section{Pendahuluan}

Penelitian Tindakan Kelas (PTK) merupakan bagian dari salah satu cara dosen untuk memperbaiki dan mengevaluasi pembelajaran di kelas. PTK seharusnya dilakukan oleh setiap dosen untuk meningkatkan kualitas pembelajaran agar tecapai sesuai dengan tujuan pembelajaran. Dosen tentunya tidak perlu khawatir dengan model yang akan diaplikasikan di dalam proses pembelajaran. Beberapa ahli dibidang pembelajaran sudah membuat inovasi model-model pembelajaran yang sangat dibutuhkan oleh para pengajar.
Model-model pembelajaran tersebut dapat diadopsi oleh para pengajar sesuai dengan kebutuhannya di kelas. Dosen dapat memilih model-model tersebut sesuai dengan kebutuhan. Pendidikan merupakan salah satu usaha meningkatkan kualitas manusia untuk mempersiapkan diri dalam rangka menghadapi tantangan IPTEKS yang semakin modern. Dalam hal ini ada beberapa ranah yang harus dikuasai setiap individu. Adapun ranah tersebut meliputi kognitif (kemampuan atau pengetahuan), afektif (sikap), dan psikomotorik (ketrampilan). Ketiga ranah tersebut saling bersinergi untuk mendukung tercapai kualitas 
setiap individu. Setiap indiviu secara sadar sudah mempersiapkan dengan mengasah setiap ranah dengan potensi yang sudah ada dalam dirinya. Secara alamiah manusia sejak lahir sudah memiliki kecerdasan pada dirinya.

Berkaitan dengan itu, peneliti akan melakukan research terkait dengan matakuliah Bahasa Inggris di Prodi Desain Interior semester 2 tahun akademik 2018/2019 dengan menggunakan model Problem Posing. Problem posing adalah yaitu pemecahan masalah dengan melalui elaborasi, yaitu merumuskan kembali masalah menjadi bagian-bagian yang lebih simple sehingga dipahami. Sintaknya adalah: pemahaman, jalan keluar, identifikasi kekeliruan, menimalisasi tulisan-hitungan, cari alternatif, menyusun soal-pertanyaan.

Matakuliah bahasa Inggris merupakan salah matakuliah MPK dengan bobot SKS 3. Untuk mengajarkan materi bahasa Inggris ini, dosen harus menggunakan strategi yang seoptimalmungkinagarprosespembelajarannya dapat berjalan sesuai dengan harapan. Dosen tidak hanya cukup dengan menerangkan materi saja tetapi juga menggunakan video, lagu, maupun kuiz untuk memotivasi mahasiswa untuk memahami materi dengan baik. Bahkan, dosen juga tidak segan-segan untuk memberikan tambahan materi ketika diluar jam perkulihan jika ada mahasiswa yang belum paham.

Peneliti tertarik untuk melakukan Penelitian Tindakan Kelas di mahasiswa Prodi Desain Interior pada matakuliah Bahasa Inggris tahun ajaran 2018/2019. Model yang akan dikembangkan adalah model problem posing di mana mahasiswa akan diajari untuk maksimal dalam mempelajari materi bahasa Inggris dengan sejelasnya-jelasnya. Sehingga pembelajaran bahasa Inggris dapat berjalan dengan optimal. Problem possing membantu dosen dan mahasiswa dalam memecahkan persoalan pembelajaran. Mahasiswa dapat berdiskusi dengan dosen terkait dengan materi perkulihaan. Dosen mengantisipasi beberapa hal teknis yang terkait dengan pembelajaran.
Matakuliah bahasa Inggris sebetulnya bukanlah sesuatu hal yang sulit akan tetapi hanya butuh pemahaman dan latihan yang kontinyu sehingga materi mudah diingat. Selain itu, mahasiswa juga dibiasakan untuk aktif berbicara dalam bahasa Inggris. Beberapa keluhan dari mahasiswa adalah kurangnya ketrampilan berbicara padahal sebetulnya dapat diatasi dengan tekun berlatih berbicara. Kemampuan berbicara dalam bahasa Inggris memang diperlukan untuk berbagai kepentingan apalagi perkembangan iptek semakin maju dan pesat. Peran pembelajaran bahasa Inggris pun sangat penting untuk melatih kemampuan berbicara mahasiswa.

Matakuliah Bahasa Inggris merupakan matakuliah teori yang wajib ditempuh semua mahasiswa semester II di Prodi Desain Interior ISI Surakarta. Matakuliah Bahasa Inggris memiliki kompetensi dalam bidang ketrampilan menggunakan bahasa Inggris baik secara struktur maupun komunikasi. Matakuliah ini memiliki kontribusi untuk membantu mahasiswa dalam mengembangkan kemampuan bahasa Inggris. Peserta yang menempuh matakuliah bahasa Inggris ini sekitar 74 mahsiswa sehingga dibutuhkan model problem posing untuk mendapatkan pembelajaran yang optimal. Adapun persoalannya adalah bagaimana teknik penerapan pembelajaran matakuliah Bahasa Inggris dengan model probem posing pada mahasiswa Prodi Desain Interior di ISI Surakarta dan bagaimana penerapan model pembelajaran probem posing melalui matakuliah bahasa Inggris dapat meningkatkan kemampuan verbal pada mahasiswa Prodi Desain Interior di ISI Surakarta.

Terdapatempat jenis Penelitian Tindakan Kelas, yaitu : (a) Jenis Diagnostik maksudnya penelitian dilakukan untuk menuntun peneliti ke arah suatu tindakan karena suatu masalah yang terjadi, misalnya adanya konflik antar siswa di kelas, adanya pertengkaran di antara siswa dan sejenisnya, (b) Jenis Partisipan maksudnya penelitian dilakukan dengan keterlibatan 
langsung peneliti dari awal sampai akhir proses, (c) Jenis Empirik maksudnya penelitian dilakukan dengan cara merencanakan, mencatat pelaksanaan dan mengevaluasi pelaksanaan dari luar arena kelas, jadi dalam penelitian jenis ini peneliti harus berkolaborasi dengan guru yang melaksanakan tindakan di kelas, (d) Jenis Eksperimental maksudnya penelitian dilakukan sebagai upaya menerapkan berbagai teknik, metode atau strategi dalam pembelajaran secara efektif dan efisien (Muhammad Faiq Dzaki, 2009).

Menurut Kemmis dan Taggart (1988), penelitian tindakan adalah suatu bentuk penelitian refleksi diri yang dilakukan oleh para partisipan dalam situasi- 3 situasi sosial (termasuk pendidikan) untuk memperbaiki praktik yang dilakukan sendiri. Dengan demikian, akan diperoleh pemahaman yang komprehensif mengenai praktik dan situasi di mana praktik tersebut dilaksanakan. Terdapat dua hal pokok dalam penelitian tindakan yaitu perbaikan dan keterlibatan. Hal ini akan mengarahkan tujuan penelitian tindakan ke dalam tiga area yaitu; (1) untuk memperbaiki praktik; (2) untuk pengembangan profesional dalam arti meningkatkan pemahaman para praktisi terhadap praktik yang dilaksanakannya; serta (3) untuk memperbaiki keadaan atau situasi di mana praktik tersebut dilaksanakan. Dalam bidang pendidikan, khususnya dalam praktik pembelajaran, Soedarsono (2005: 2) menjelaskan karakteristik penelitian tindakan kelas berbeda secara konseptual dan fundamental, yaitu PTK sebagai : (a) an inquiry on practice from within, berarti kegiatan PTK didasarkan pada masalah keseharian yang dirasakan, dan dihayati dalam melaksanakan pembelajaran yang selalu muncul, sekalipun mahasiswa yang dihadapi berlainan pada setiap semesternya, (b) a collaborative effort and or participatives, mengisyaratkan bahwa tindakan dan upaya perbaikan dilakukan bersama-sama mahasiswa secara kolaboratif dan partisipatif. Mahasiswa bukan hanya diperlakukan sebagai obyek ynag dikenai tindakan, tetapi juga sebagai pelaku aktif dalam kegiatan yang dilakukan dosen untuk mencapai tujuan yang disepakati, (c) a reflective pratice mode public, berarti menghendaki agar keseluruhan proses implementasi tindakan dipantau dengan mempergunakan metode dan alat yang dapat dipertanggungjawabkan secara ilmiah. Dengan demikian laporan PTK akan dapat memenuhi kaidah metodologi ilmiah dan kesimpulan atau temuan yang berupa model atau prosedur upaya perbaikan, peningkatan dan perubahan ke arah yang lebih baik dan dapat disebarluaskan (diseminasi).

Ada beberapa tujuan yang menjadi target dari penelitian tindakan kelas yaitu : (a) melakukan suatu tindakan perbaikan, perubahan, dan peningkatan yang lebih baik dalam mencari solusi dari permasalahan di kelas, (b) menemukan suatu model yang inovasi dalam pengembangan pembelajaran, (c) menemukan prosedur tindakan yang dapat mengurai persoalan pada saat proses pembelajaran (Rosmiati, 2017).

Elliot (1982) menyatakan bahwa penelitian tindakan merupakan kajian tentang situasi sosial dengan maksud untuk meningkatkan kualitas tindakan di dalamnya. Seluruh prosesnya telaah, diagnosis, perencanaan, pelaksanaan, pemantauan dan pengaruh menciptakan hubungan yang diperlukan antara evaluasi diri dan perkembangan profesional.

Berkaitan dengan itu, Richart Winter menyebutkan adanya 6 karakteristik PTK yaitu : (1) Kritik refleksif adalah adanya upaya evaluasi atau penilaian yang didasarkan catatan data yang telah dibuat, dan cara refleksi sehingga dapat ditransformasikan menjadi pertanyaaan dan alternatif yang mungkin dapat disarankan, (2) Kritik dialektis adalah adanya kesediaan peneliti untuk melakukan kritik pada fenomena yang ditelitinya. Dalam hal ini guru perlu menafsirkan data dengan konteks yang harus ada, menganalisis katagori 
yang berbeda untuk menemukan kesamaan, dan menangkap isyarat bahwa fenomena akan dapat berubah, (3) Kolabortif adalah adanya kerjasama (atasan, sejawat, siswa dan lainlain), yang dapat dipergunakan sebagai sudut pandang. Peneliti dalam PTK adalah bagian dari situasi yang diteliti, peneliti sebagai pengamat juga terlibat langsung dalam proses situasi tersebut. Kolaborasi pada anggota dalam situasi itu yang memungkinkan proses itu berlangsung. Untuk menjamin kolaborasi perlu mengumpulkan semua sudut pandang anggota yang menggambarkan struktur situasi yang diteliti. Tetapi perlu diingat bahwa peneliti mempunyai kewenangan dalam penelitian, sehingga tidak mutlak semua pandangan harus digunakan, (4) Resikonya adalah adanya keberanian peneliti untuk mengambil resiko pada waktu berlangsungnya penelitian. Resiko yang mungkin muncul adalah melesetnya hipotesis, dan kemungkinan tuntutan untuk melakukan transformasi. Peneliti mungkin berubah pandangannya, karena melihat sendiri pertentangan yang ada, (5) Struktur majemuk adalah adanya pandangan bahwa penelitian ini mencakup berbagai unsur yang terlibat, agar bersifat komprehensif. Misal jika penelitian pada pengajaran, maka situasinya harus mencakup guru, murid, tujuan pembelajaran, interaksi kelas, hasil dll, dan (6) Internaslisasi teori dan praktik adalah adanya pandangan bahwa teori dan praktik bukan dua hal yang berbeda, tetapi merupakan dua tahap yang berbeda, yang saling tergantung, dan keduanya berfungsi untuk mendukung transformasi. Dari karakteristik di atas menggambarkan bahwa PTK ada perbedaan dengan penelitian lainnya.

Pada dasarnya PTK terdiri dari 4 langkah di atas yaitu Planning (perencanaan), Acting (tindakan), Observing (pengamatan), dan Refelecting (refleksi). Namun sebelumnya tahapan-tahapan di atas diawali dengan pra PTK yaitu : (a) Identifikasi masalah, (b) Rumusan masalah, (c) Analisis masalah, dan (d) Rumusan hipotesis tindakan.
Berkaitan dengan itu, Borg and Gall (1989:772) mengemukakan bahwa Educational Research and Development biasa juga disebut Research Based Development. " Educational Research and Development is a process used to develop and validate educational products"). Penelitian dan Pengembangan adalah suatu proses atau langkah-langkah untuk mengembangkan suatu produk baru atau menyempurnakan produk yang telah ada. Yang dimaksud dengan produk dalam konteks ini adalah tidak selalu berbentuk hardware (buku, modul, alat bantu pembelajaran di kelas dan laboratorium), tetapi bisa juga perangkat lunak (software) seperti program untuk pengolahan data, pembelajaran di kelas, perpustakaan atau laboratorium, ataupun model- model pendidikan, pembelajaran pelatihan, bimbingan, evaluasi, manajemen, dan lainlain. Karakteristik Research \& Development adalah penelitian ini berbentuk "siklus", yang diawali dengan adanya kebutuhan, permasalahan yang membutuhkan pemecahan dengan suatu produk tertentu. Dalam bidang pendidikan, produk-produk yang dihasilkan melalui penelitian R \& D diharapkan dapat meningkatkan produktivitas pendidikan, yaitu lulusan yang jumlahnya banyak, berkualitas, dan relevan dengan kebutuhan. Produk-produk pendidikan misalnya kurikulum yang spesifik untuk keperluan pendidikan tertentu, metode mengajar, media pendidikan, buku ajar, modul, kompetensi tenaga kependidikan, sistem evaluasi, model uji kompetensi, penataan ruang kelas, model unit produksi, Khusus dalam bidang pengembangan kurikulum, para pengembang jarang menggunakan metode penelitian dan pengembangan. Para pengembang kurikulum seringkali menggunakan metode atau pendekatan filosofis dan akademik dan kurang memberikan perhatian pada temuan-temuan empiris. Pendekatan Reseach and Development ( R \& D) dalam pendidikan meliputi sepuluh langkah, yaitu: 


\section{a. Studi Pendahuluan}

Langkah pertama ini meliputi analisis kebutuhan, studi pustaka, studi literatur, penelitian skala kecil dan standar laporan yang dibutuhkan. Analisis Kebutuhan: Untuk melakukan analisis kebutuhan ada beberapa kriteria, yaitu 1) Apakah produk yang akan dikembangkan merupakan hal yang penting bagi pendidikan? 2) Apakah produknya mempunyai kemungkinan untuk dikembangkan? 3) Apakah SDM yang memiliki keterampilan, pengetahuan dan pengalaman yang akan mengembangkan produk tersebut ada? 4) Apakah waktu untuk mengembangkan produk tersebut cukup? Studi Literatur: Studi literatur dilakukan untuk pengenalan sementara terhadap produk yang akan dikembangkan. Studi literatur ini dikerjakan untuk mengumpulkan temuan riset dan informasi lain yang bersangkutan dengan pengembangan produk yang direncanakan. Riset Skala Kecil: Pengembang sering mempunyai pertanyaan yang tidak bisa dijawab dengan mengacu pada reseach belajar atau teks professional. Oleh karenanya pengembang perlu melakukan riset skala kecil untuk mengetahui beberapa hal tentang produk yang akan dikembangkan.

\section{b. Merencanakan Penelitian}

Setelah melakukan studi pendahuluan, pengembang dapat melanjutkan langkah kedua, yaitu merencanakan penelitian. Perencaaan penelitian R \& D meliputi: 1) merumuskan tujuan penelitian; 2) memperkirakan dana, tenaga dan waktu; 3) merumuskan kualifikasi peneliti dan bentuk-bentuk partisipasinya dalam penelitian.

\section{c. Pengembangan Desain}

Langkah ini meliputi: 1) Menentukan desain produk yang akan dikembangkan (desain hipotetik); 2) menentukan sarana dan prasarana penelitian yang dibutuhkan selama proses penelitian dan pengembangan; 3) menentukan tahap-tahap pelaksanaan uji desain di lapangan; 4) menentukan deskripsi tugas pihak-pihak yang terlibat dalam penelitian.

\section{d. Preliminary Field Test}

Langkah ini merupakan uji produk secara terbatas. Langkah ini meliputi: 1) melakukan uji lapangan awal terhadap desain produk; 2) bersifat terbatas, baik substansi desain maupun pihak-pihak yang terlibat; 3) uji lapangan awal dilakukan secara berulangulang sehingga diperoleh desain layak, baik substansi maupun metodologi.

e. Revisi Hasil Uji Lapangan Terbatas

Langkah ini merupakan perbaikan model atau desain berdasarakan uji lapangan terbatas. Penyempurnaan produk awal akan dilakukan setelah dilakukan uji coba lapangan secara terbatas. Pada tahap penyempurnaan produk awal ini, lebih banyak dilakukan dengan pendekatan kualitatif. Evaluasi yang dilakukan lebih pada evaluasi terhadap proses, sehingga perbaikan yang dilakukan bersifat perbaikan internal.

\section{f. Main Field Test}

Langkah merupakan uji produk secara lebih luas. Langkah ini meliputi 1) melakukan uji efektivitas desain produk; 2) uji efektivitas desain, pada umumnya, menggunakan teknik eksperimen model penggulangan; 3) Hasil uji lapangan adalah diperoleh desain yang efektif, baik dari sisi substansi maupun metodologi.

g. Revisi Hasil Uji Lapangan Lebih Luas Langkah ini merupakan perbaikan kedua setelah dilakukan uji lapangan yang lebih luas dari uji lapangan yang pertama. Penyempurnaan produk dari hasil uji lapangan lebih luas ini akan lebih memantapkan produk yang kita kembangkan, karena pada tahap uji coba lapangan sebelumnya dilaksanakan dengan adanya kelompok kontrol. Desain yang digunakan adalah pretest dan posttest. Selain perbaikan yang bersifat internal. Penyempurnaan produk ini didasarkan pada evaluasi hasil sehingga pendekatan yang digunakan adalah pendekatan kuantitatif.

\section{h. Uji Kelayakan}

Langkah ini meliputi sebaiknya dilakukan dengan skala besar: 1) melakukan uji efektivitas dan adaptabilitas desain produk; 2) uji efektivitas 
dan adabtabilitas desain melibatkan para calon pemakai produk; 3) hasil uji lapangan adalah diperoleh model desain yang siap diterapkan, baik dari sisi substansi maupun metodologi.

i. Revisi Final Hasil Uji Kelayakan Langkah ini akan lebih menyempurnakan produk yang sedang dikembangkan. Penyempurnaan produk akhir dipandang perlu untuk lebih akuratnya produk yang dikembangkan. Pada tahap ini sudah didapatkan suatu produk yang tingkat efektivitasnya dapat dipertanggungjawabkan. Hasil penyempurnaan produk akhir memiliki nilai "generalisasi" yang dapat diandalkan.

j. Desiminasi dan Implementasi Produk Akhir

Laporan hasil dari R \& D melalui forum-forum ilmiah, ataupun melalui media massa. Distribusi produk harus dilakukan setelah melalui quality control. Teknik analisis data, langkah-langkah dalam proses penelitian dan pengembangan dikenal dengan istilah lingkaran research dan development menurut Borg and Gall terdiri atas :(a) meneliti hasil penelitian yang berkaitan dengan produk yang akan dikembangkan, (b) mengembangkan produk berdasarkan hasil penelitian, (c). uji lapangan (d) mengurangi devisiensi yang ditemukan dalam tahap ujicoba lapangan. Ada satu model desain pembelajaran yang lebih sifatnya lebih generik yaitu model ADDIE (Analysis-Design-DevelopImplement- Evaluate). ADDIE muncul pada tahun 1990-an yang dikembangkan oleh Reiser dan Mollenda.Salah satu fungsinya ADIDE yaitu menjadi pedoman dalam membangun perangkat dan infrastruktur program pelatihan yang efektif, dinamis dan mendukung kinerja pelatihan itu sendiri.

Penelitian tindakan kelas ini dilakukan di kelas dengan mengadakan pendekatan ke mahasiswa di Prodi Desain Interior Fakultas Seni Rupa dan Desain ISI Surakarta. Penelitian dilakukan di Ruang kuliah Gedung V Kampus II Mojosongo. Tempat perkuliahan di gedung $\mathrm{V}$ ini representatif yang mendukung proses pembelajaran. Di samping ruang kelas yang nyaman juga suasana cukup kondusif dengan didukung udara yang masih sejuk. Pemilihan tempat didasarkan pada beberapa pertimbangan antara lain ruang tersebut merupakan kelas untuk pembelajaran matakuliah teori. Penelitian berlangsung selama 6 bulan, yakni bulan Februari sampai dengan bulan Juli 2018. Adapun rencana kegiatan sebagai berikut.

Persiapan Penelitian

a. Koordinasi Persiapan Tindakan

b. Pelaksanaan( Perencanaan, Tindakan, Monitoring, Evaluasi, dan Refleksi),

c. Penyusunan Laporan Penelitian

Adapun yang menjadi subjek penelitian tindakan kelas ini adalah mahasiswa yang mengambil Matakuliah Bahasa Inggris Tahun Akademik 2018 Program Studi Desain Interior Fakultas Seni Rupa dan Desain Institut Seni Indonesia Surakarta. Sementara dosen pengampu Mata kuliah Seminar dijadikan subjek penelitian.

\section{Penerapan Pembelajaran Matakuliah Bahasa Inggris dengan Model Problem Posing pada Mahasiswa Prodi Desain Interior di ISI Surakarta}

Model pembelajaran yang digunakan di Prodi Desain Interior dengan kapasitas 74 mahasiswa di kelas menggunakan model problem posing dengan tujuan untuk biasa mengakumulasi semua kebutuhan yang menjadi tujuan dari pembelajaran Bahasa Inggris. Melihat kapaistas jumlah mahasiswa yang tidak ideal untuk matakuliah teori maka dosen dapat memilih model pembelajaran yang cocok untu digunakan di kelas. Adapun model ini dapat digunakan untuk memotivasi mahasiswa agar lebih aktif di dalam proses pembelajaran. Matakuliah Bahasa Inggris lebih menekankan pada kemampuan verbal pada mahasiswa. Adapun kemampuan verbal menjadi hal penting ketika sesorang sedang dalam proses komunikasi. Kemampuan verbal adalah kemampuan seseorang dalam berkomunikasi menggunakan bahasa sebagai 
media komunikasi. Bahasa menjadi sarana penting dalam sebuah komunikasi. Sifat bahasa yang universal menyebabkan bahasa menjadi sesuatu yang lebih dinamis berkembang di masyarakat.

Problem posing didesain untuk menjawab solusi yang seringkali dicari seorang pengajar yang mengalami beberapa kendala dalam proses pembelajaran. Mengingat jumlah mahasiswa di desain interior yang kapasitasnya melebihi ukuran kelas ideal maka bebeeapa persoalan seperti kekurang aktifan mahasiswa di kelas dalam mengikuti matakuliah bahasa Indonesia dapat diminimalkan. Problem yang dihadapi dosen tidaklah jauh berbeda dengan pengajar lainnya. Salah satunya adalah memotivasi mahasiswa agar lebih aktif berdiskusi maupun dalam menjawab pertanyaan dosen. Mahasiswa terkesan lebih pasif ketika saat proses pembelajaran. Dosen terkesan lebih aktif menjelaskan materi dengan memberi beberapa contoh. Sebagai contoh ketika dosen menyuruh mahasiswa untuk bercerita di depan kelas dengan topik bebas menggunakan bahasa Inggris yang benar belum semuanya benar. Masih terjadi kesalahan pengucapan maupun penyusunan kalimat yang sesuai dengan tenses. Dosen masih menemukan bentuk pola kalimat yang diucapkan terdapat kekeliruan. Begitupula dengan bentuk kata kerja dalam beberapa bentuk juga seringkali masih keliru. Setelah beberapa mahasiswa melakukan presentasi, dosen dapat melakukan evaluasi beberapa kesalahan yang dilakukan mahasiswa agar tahu kesalahan yang sudah dilakukan.

Kemampun vervbal menjadi hal penting yang harus dikuasi setiap orang. Bahasa Inggris menjadi bahasa internasional di dunia maka sudah sewajarnya setiap orang juga harus sedikit banyak paham dan lebih baik juga kalau biasa meggunakan dengan benar. Apalagi untuk beberapa tahun ini adanya pasar bebas (MEA) yang masuk ke Indonesia maka bahasa Inggris menjadi sebuah kebutuhan untuk bisa berkomunikasi. Kemampuan menggunakan bahasa dengan baik tidaklah diperoleh dengan cara yang singkat (instant). Proses untuk menguasai sebuah bahasa dimulai dari sebuah usaha secara rutin dan bertahap belajar bahasa. Tidak secara otomatis sehari sampai dua hari belajar bahasa kemudian menjadi lancar dan benar. Kemampuan verbal diperoleh dengan cara memperkaya kosakata dalam bahasa Inggris. Sehingga ketika berkomunasi, orang sudah memiliki referensi kosakata yang luas. Hampir bisa dihitung kalau rata-rata kemampuan bahasa Inggris pada level pengguna pasif. Artinya seseorang itu memiliki kemampuan bahasa Inggris hanya untuk struktur, grammar, dan lain-lain secara tertulis. Sementara yang dikatakan sebagai pengguna bahasa Inggris aktif adalah seseorang yang memiliki kemapuan untuk berkomunikasi secara lisan dengan baik dan benar.

Kondisi yang terjadi di kalangan mahasiswa masih ditemukan kesulitan berkomunikasi dalam Bahasa Inggris. Hal ini terjadi karena tidak terbiasa berkomunikasi secara rutin menggunakan Bahasa Inggris. Untuk itu, penggunaan pemakaian bahasa memang sebaiknya rutin setiap hari paling tidak untuk mengasah kemampuan vocal dengan baik. Selain itu, penggunaan kosakat bahasa pun harus sering ditambah. Artinya harus sering membaca untuk memperkaya kosakata pada masing-maisng individu.

Selain kemampuan komunikasi verbal dalam bahasa Inggris juga perlu ditekankan pada hal penerjemahan dalam bahasa Inggris. Kemampuan menerjemahkan menjadi hal yang menarik untuk membantu mahasiswa memperkaya kosakata perbendaharaan kata bahasa Inggris. Selain itu, untuk mengasah kecerdasan mahasiswa.

\footnotetext{
Penerapan Model Pembelajaran Problem Posing melalui Matakuliah Bahasa Inggris yang dapat Meningkatkan Kemampuan Verbal pada Mahasiswa Prodi Desain Interior di ISI Surakarta
} 
Matakuliah Bahasa Inggris disajikan pada di Program Studi Desain Interior pada semester genap tahun 2018 dengan jumlah peserta mahasiswa 74 mahasiswa. Untuk memperoleh hasil pembelajaran yang optimal maka disusun rencana pembelajaran untuk memudahkan evaluasi sebagai berikut. (1) Rencana Tindakan, (2) Pelaksanaan, (3) Pengamatan, dan (4) Refleksi.

\section{Siklus I}

Waktu pelaksanaan pada tanggal 26 Februari, 5, dan 12 Maret 2018, yakni pertemuan ke I, II, dan III. Pada pertemuan pertama dosen menyampaikan tentang kontrak kuliah yang harus disepakati oleh mahasiswa yang mengambil matakuliah Bahasa Inggris. Peserta yang mengikuti matakuliah bahasa Inggris aada 74 mahasiswa sehingga perlu ruang kuliah yang luas dan cukup representative untuk mahasiswa. Dosen harus menyiapkan materi yang sesuai dengan RPS tang disusun selama satu semester. RPS menjadi pijakan dosen dalam mengajar dalam satu semester. Selanjutnnya di pertemun Pertama dosen memberikan kontrak perkuliahaan yang harus ditaati mahsiswa. Kemudian dosen memberikan materi tentang struktur dasar bahasa Inggris . Harapannya dosen bahwa setelah mengikuti perkuliahan ini, mahasiswa dapat mengingat kembali struktur dasar bahasa Inggris.

\section{Pada siklus I, kegiatan yang dilakukan meliputi:}

1. Rencana Tindakan:

a. Dosen menyiapkan materi untuk dipelajari mahasiswa.

b. Dosen memnginformasikan bahan materi dan literatur yang dijadikan sumber pembelajaran.

c. Dosen membuat contoh-contoh yang dapat diadopsi oleh mahasiwa.

d. Dosen menyiapkan materi tugas yang bisa dikerjakan mahasiswa.

e. Dosen menentukan model stategi pembelajaran dengan melihat tingkat kemudahan dan kerumitan dikelas.

f. Dosen menyiapkan indikator penilaian untuk sebagai bahan evaluasi.

Adapun objek mahasiswa dari PTK ini adalah dengan melihat keaktifan mahasiswa dalam mengikuti perkulihaan. Keaktifan dilihat dari keseriusan mendengar dosen ketika menyampaikan materi, keaktifan berdiskusi, dan lain-lainnya. Sedangkan objek dosen dalam PTK ini adalah kemampuan dosen menyampaikan materi dengan Teknik yang baik sehingga mahasiswa mampu menyerap dengan maksimal.

\section{Pelaksanaan Tindakan}

Kegiatan pada pertemuan ke II dan III adalah mahaiswa dapat menyusun dan menerjemahkan kalimat Bahasa Inggris yang menggunakan to be dengan benar. Secara garis besar tindakan awal yang dilakukan pada pertemuan ke 2 dan 3 sebagai berikut.

a. Dosen mengenalkan ciri-ciri kalimat non verbal.

b. Dosen memberikan contoh bagaimana menyusun kalimat non verbal dengan menggunakan to be yang benar.

c. Dosen menjelaskan kalimat non verbal dengan predikat adjective noun dan adverb.

d. Dosen memberikan contoh penjelasan mengenai cara menerjemahkan kalimat non verbal Bahasa Inggris ke dalam Bahasa Indonesia dengan benar.

Pada pertemuan ke II dan III, dosen menekankan kepada mahasiswa untuk bisa menyusun kalimat non verbal dengan menggunakan to be dengan benar.

Pada minggu ke II dan III, Pelaksanaan tindakan, meliputi: Setelah dosen melanjutkan materi dari minggu pertama selanjutnya langsung masuk ke materi utama yaitu menyusun kalimat non verbal dengan 
menggunakan to be dengan benar. Selanjutnya mahasiswa juga harus paham dengan ciriciri kalimat non verbal. Pada bagian penutup mahasiwa nnati dapat memiliki kemampuan untuk menerjemahkan kalimat non verbal Bahasa Inggris ke dalam Bahasa Indonesia. Mengingat peserta di kelas teori berjumlah 74 orang maka dosen memiliki strategi dengan membuat kelompok masing-masing 3 orang mahasiwa dalam satu kelompok. Dengan pembagian kelompok lebih efisien dan efektif dalam proses pembelajaran. Dosen menentukan tema yang harus dipilih mahasiswa yang terkait dengan bidang desain. Mahasiwa bebas memilih sumber bahan yang berbahasa inggris dengan memperhatikan beberapa ketentuan yang sudah disepakti dengan dosen. Selanjutnya, mahasiwa secara perwakilan dapat memaparkan hasil menerjemahkan kalimat non verbal.

\section{Pengamatan}

Pengamatan dilakukan oleh dosen pengampu matakuliah Bahasa Inggris di Prodi Desain Interior. Sasaran yang diamati sebagai berikut.

1. Jumlah kehadiran mahasiswa masuk di kelas

2. Keseriusan mahasiswa menangkap informasi

3. Keaktifan mahasiswa di dalam kelas

4. Kerjasama masing-masing kelompok

5. Jumlah mahasiswa yang membuat tugas kelompok

6. Keberanian mahasiswa memaparkan hasil tuga kelompok di depan kelas

7. Kemampuan menerjemahkan dengan benar sesuai topik yang sudah ditentukan.

Pada siklus pertama setelah diadakan pengamatan baru sekitar 60 persen mahasiswa yang menerjemahkan dengan benar dan sesuai dengan topik. Sedangkan sisanya sekitar 40 persen masih terdapat beberapa kesalahan menerjemahkan.

\section{Refleksi}

Setelah dilakukan kajian secara menyeluruh pada pertemuan ke I, II, III ternyata masih ditemukan beberapa masalah yang memerlukan pengubahan model strategi mengajar maupun penugasan. Untuk model menerjemahkan secara kelompok dianggap kurang membuahkan hasil yang maksimal karena mahasiswa cenderung lebih pasif. Kemudian dalam kerja kelompok juga masih ditemukan belum ada kerjasama yang baik. Maka dari itu akan dipelajari pada siklus berikutnya agar memperoleh hasil yang lebih baik.

\section{Siklus II}

Siklus II pada dilaksanaan tanggal 19, 26 Maret, dan 2 April 2018 pada pertemuan IV, V, dan VI. Paada siklus II ini output yang diharapkan dari mahasiswa adalah dapat menyusun dan menerjemahkan kalimat dalam simple present dan simple past tense.

Pada siklus ini yang dilakukan adalah: (1) Rencana Tindakan, (2) Pelaksanaan, (3) Pengamatan, dan (4) Refleksi.

\section{Rencana Tindakan}

Dosen melakukan persiapan berdasarkan pada refleksi siklus I. Persiapan yang dilakukan adalah:

a. Dosen memberikan materi seminggu sebelumnya untuk dipelajari mahasiswa terlebih dahulu.

b. Dosen menjelaskan materi di kelas

c. Dosen menyiapkan Teknik pembelajaran yang lebih efisien dan efektif.

d. Dosen menyiapkan beberapa contoh polapola kalimat yang bisa diadopsi oleh mahasiswa.

e. Dosen menyiapkan alat untuk pengamatan. Objek mahasiswa yang diperhatikan adalah dkeaktifan mahasiswa di kelas, ketelitian dalam membuat pola-pola kalimat dengan benar sesuai tenses.

Objek dosen adalah indikator keberhasilan tugas mahasiswa. 


\section{Pelaksanaan Tindakan}

Pada siklus ke II, pembelajaran mengenalkan kalimat positive, negative, dan interrogative dalam simple present dan past tense masih dalam katagori terkendali. Mahasiswa mendapat bentuk tugas yang diberikan masih dalam pengendalian dosen secara penuh. Secara rinci tindakan awal yang dilakukan:

a. Dosen menyampaikan materi tentang ciriciri kalimat dalam simple present.

$b$. Dosen menyampaikan materi tentang ciriciri kalimat simple past .

c. Dosen menjelaskan cara menyusun kalimat dalam simple present.

$d$. Dosen menjelaskan cara menyusun kalimat dalam simple past.

e. Dosen menjelaskan cara menerjemahkan kalimat dalam simple present

$f$. Dosen menjelaskan cara menerjemahkan kalimat dalam simple past.

$g$. Dosen menjelaskan kalimat positive dalam simple present.

$h$. Dosen menjelaskan kalimat negative dalam simple present.

$i$. Dosen menjelaskan kalimat positif dalam simple present.

$j$. Dosen menjelaskan kalimat negative dalam simple present.

$k$. Dosen menjelaskan ciri-ciri kalimat dalam present.

l. Dosen menjelaskan ciri-ciri kalimat dalam past continuos tense.

Pada tahap ini dosen menugaskan mahasiswauntukmenyusundanmenerjemahkan kalimat dalam simple present dan simple past tense. Dari sejumlah mahasiswa yang hadir 70 persen sudah menunjukan hasil yang lumayan baik. Beberapa mahaiswa masih keliru dalam menyusun pola-pola kalimat dengan benar. Masih ada kendala kecil untuk menyelesaikan secara cepat sesuai waktu pembelajaran.

\section{Pengamatan}

Pengamatan dilakukan oleh dosen pengampu. Sasaran yang diamati:

a. Jumlah mahasiswa yang hadir di kelas.

b. Jumlah mahasiswa yang mengerjakan tugas dengan tuntas

c. Jumlah mahasiswa yang mengerjakan tugas dengan benar.

d. Jumlah mahasiswa yang berani menyampaikan tugas di depan kelas

e. Kemampuan analisis hasil jawaban tugas mahasiswa

Berdasarkan pengamatan pada siklus II sudah menunjukkan perbaikan dalam metode mengajar dari siklus I baru $60 \%$ yang benar sekarang naik menjadi $70 \%$ yang menjawab dengan benar. Aertinya dosen mengubah Teknik mengajar sehingga hasil dapat secara signifikan dapat naik menjadi baik. Pada pembelajaran ini dosen juga melakukan pantauan secara langsung ketika mahasiswa sedang mengerjakan tugas dengan baik.

\section{Refleksi}

Pada pertemuan ke IV, V, dan VI sudah ada perbaikan dengan meningkatkannya prosentase pemahaman mencapai $70 \%$. Kemampuan mahasiswa yang mencapai $70 \%$ sudah menunjukkan hasil yang lumayan baik. Karena kelas yang gemuk untuk teori maka dibutuhkan pendampingan yang intens ketika mahasiswa sedang mengerjakan tugas. Dengan model pengawasan seperti itu biasanya hasilnya akan lebih baik.

\section{Siklus III}

Waktu pelaksanaan tanggal 9 dan 16 April 2018 yakni pertemuan ke VII, VIII, Dosen menjelaskan ciri-ciri kalimat dalam present dan past future tense. Dosen juga mengajarkan tentang menyusun dan menerjemahkan kalimat dalam present dan past perfect tense. Pada siklus III, kegiatan yang dilakukan meliputi:

\section{Rencana Tindakan:}

a. Dosen menyiapkan materi sesuai dengan RPS yang dibuat.

b. Dosen memberikan materi seminggu 
sebelum pembelajaran di mulai.

c. Dosen menyusun strategi pembelajaran yang dapat memudahkan pembelajaran di kelas.

d. Dosen menyiapkan kuiz

e. Dosen membuat contoh soal-soalyang akan dikerjakan mahasiswa

Objek pengamatan pada mahasiswa meliputi prosente mahasiswa tyang sudah mempelajari materi, keaktifan di kelas, umpan balik dari mahasiswa. Adapun Objek dosen adalah Strategi penyampaian, bentuk tugas, dan evaluasi mahasiwa.

\section{Pelaksanaan Tindakan}

Pada siklus ke III, Pembelajaran mengenai cara menyususn menerjemahkan kalimat dalam bahasa Indonesia yang benar . Secara garis besar tindakan awal yang dilakukan pada pertemuan ke VII dan VIII:

a. Dosen menerangkan ciri-ciri kalimat dalam bentuk present.

b. Dosen menerangkan ciri-ciri kalimat dalam future tense.

c. Dosen menjelaskan tentang kalimat dalam past tene

d. Dosen menjelaskan tentang past continuous tense dengan benar.

e. Dosen menjelaskan tentang kalimat positive

f. Dosen menjelaskan tentang kalimat negative

g. Dosen menjelaskan tentang kalimat interrogative

Pada tahap ini dosen menugaskan mahasiswauntukmenyusundanmenerjemahkan kalimat dalam present dan past perfect tense. Sebelumnya mahasiswa sudah terlebih dahulu mendapat tugas menyusun kalimat positive, kalimat negative, dan kalimat interogative. Dari sejumlah mahasiswa yang hadir 75 persen sudah menunjukan hasil yang baik. Beberapa mahaiswa sudah dapat membedakan kalimat positive, negative, dan interogative.
Mahasiswa juga sudah menerjemahkan dengan tingkat kebenarannya sekitar $75 \%$ dari jumlah mahasiswa sebanyak 73 Mahasiswa. Artinya ada sekitar $25 \%$ yang masih memerlukan bimbingan secara intens.

\section{Pengamatan.}

Pengamatan dilakukan oleh dosen pengampu. Sasaran yang diamati:

a. Jumlah mahasiswa yang hadir di kelas

b. Jumlah mahasiswa yang menyelesaikan tugas

c. Jumlah mahasiswa yang sudah selesai menerjemahkan

c. Kemampuan menerjemahkan ke dalam bahasa Indonesia

Berdasarkan pengamatan pada siklus III sudah menunjukkan perbaikan dalam metode mengajar dari siklus II baru $70 \%$ yang benar sekarang naik menjadi $75 \%$ yang menjawab dengan benar. Dosen sudah mengubah model pemeblajaran dengan langsung mendampingi per kelompok mahasiswa yang sedang mengerjakan tugas. Dengan begitu mahasiswa paham kesalahan yang diperbuat.

\section{Refleksi}

Pada pertemuan ke VII dan VIII sudah ada perbaikan dengan meningkatkannya prosentase pemahaman mencapai $75 \%$. Ada kenaikan sekitar $5 \%$ dari kemampuan yang diperoleh pada siklus III ini. Hal ini menunjukan sudah dilakukan pengamatan dalam pembelajaran. Dosen kemudian menyusun stategi yang sesuai dengan kondisi di kelas. Hasilya sudah menunjukkan kenaikan $5 \%$. Mencermati dari sikulus I, II, dan III mengalami kenaikan lumayan signifikan.

\section{Siklus IV}

Siklus IV dilaksanaan pada pertemuan ke IX pada tanggal 23 April 2018 . Pada siklus IV diadakan evaluasi tengah semester (MID Semester). kegiatan yang dilakukan meliputi: 


\section{Rencana Tindakan:}

a. Dosen menginformasikan sebelumnya kepada mahasiswa untuk mempersiapkan diri

b. Dosen memberikan kisi-kisi materi ujian mid semester

c. Dosen menyiapkan soal ujian tengah semstester

Objek mahasiswa yaitu hasil ujian tengah semester. Objek dosen adalah mengkoreksi hasil ujian tengah semester.

\section{Pelaksanaan Tindakan}

Pada siklus ke IV diadakan ujian tengah semester. Pelaksanaan tindakan, meliputi.

a. Dosen menjadwalkan ujian tengah semester.

b. Dosen menyiapkan soal ujian tengah semseter

\section{Pengamatan.}

Pengamatan dilakukan oleh dosen pengampu. Sasaran yang diamati:

a. Jumlah mahasiswa yang ikut ujian tengah semester

b. Jumlah mahasiswa yang mengerjakan ujian tengah semester dengan benar

c. Kemampuan mahaasiswa mengerjakan soal ujian tengah semester.

Berdasarkan pengamatan pada siklus IV semua mahasiswa mengikuti ujian tengah semester. Nilai tengah semester akan diakumulasi ke dalam nilai akhir semester.

\section{Refleksi}

Setelah dilakukan ujian tengah semester dapat dismpulkan rata-rata mahasiswa mengerjakan kriteria sangat baik, baik ,dan cukup. Artinya dosen harus mengubah model pembelajaran menjadi lebih baik lagi. Meskipun yang cukup jumlahnya tidak banyak.

\section{Siklus V}

Siklus $\mathrm{V}$ pada dilaksanaan pada pertemuan X, X1, XII, tanggal, 30 April, 7 , 14 Mei 2018 . Pada siklus V, kegiatan yang dilakukan meliputi:

\section{Rencana Tindakan:}

a. Dosen memberikan materi sesuai dengan RPS sebelum perkulihaan.

b. Dosen menjelaskan materi di kelas dengan model ceramah.

c. Dosen menyusun soal latihan untuk menguatkan materi perkulihaan.

d. Dosen menyiapkan evaluasi setelah dilakukan pantauan terhadap mahasiswa.

e. Dosen menyiapkan alat pengamatan.

Adapun objek mahasiswa adalah keaktifan mahasiswa di kelas, kemampuan mahasiswa menjawab pertanyaan, dan kemampuan mahasiswa mengerjakan tugas yang diberikan dosen. Sedangkan, objek dosen adalah Strategi penyampaian, bentuk tugas, dan alat evaluasi.

\section{Pelaksanaan Tindakan}

Pada siklus ke V ini dosen menerangkan tentang penyusunan kalimat passive dalam semua tenses dengan benar. Adapun model perkulihaan dengan metode ceramah yang dilanjutkan dengan pemberian latihan kepada mahasiswa.

Pelaksanaan tindakan, meliputi: setelah dosen menjelaskan materi, dengan urutan sebagai berikut.

a. Dosen menjelaskan tentang ciri-ciri kalimat pasif dalam semua tenses.

b. Dosen menyusun kalimat pasif dalam semua tenses dengan benar

c. Dosen menerjemahkan kalimat pasif dengan benar

d. Dosen menjelaskan ciri-ciri kalimat yang menggunakan bentuk degree of comparison

e. Dosen menjelaskan cara menyusun kalimat yang menggunakan bentuk degree of comparison yang benar

f. Dosen menjelaskan cara menerjemahkan kalimat yang menggunakan bentuk degree of comparison yang benar.

g. Dosen menjelaskan ciri-ciri kalimat compound sentences 
h. Dosen menjelaskan tentang coordinating conjuction dalam compound sentence.

Dosen memberi penegasan kepada mahasiswa bahwa keaktifan dan keberanian menyampaikan tugas serta keberanian tampil di depan kelas menjadi nilai tambah yang akan diakumulasi pada akhir semester.

\section{Pengamatan.}

Pengamatan dilakukan oleh dosen pengampu. Sasaran yang diamati:

a. Jumlah mahasiswa yang hadir di kelas

b. Jumlah mahasiswa yang berani tampil di depan kelas

c. Kemampuan mahasiswa dalam mengerjakan tugas dari dosen.

Berdasarkan pengamatan pada siklus $\mathrm{V}$ ada peningkatan hasil yang signifikan. Jumlah yang hadir, jumlah yang menyampaikan hasil tugas, dan kualitas kemampuan tampil di kelas sudah meningkat lebih banyak dibandingkan di siklus V. Hasil analisis menunjukan ada keberanian mahasiwa untuk tampil mempresentasikan hasil tugas yang diberikan dosen.

\section{Refleksi}

Tahapan dalam pembelajaran pada siklus $\mathrm{V}$ ini banyak mahasiswa yang sudah antuasias untuk berani maju di depan kelas menyampiakan hasil tugas yang diberikan dosen. Berdasarkan pengamatan ada peningkatan yang baik untuk memotivasi mahasiswa berani untuk secara vocal berbicara di depan kelas berkaitan dengan tugas yang diberikan tugas sesuai yang direncanakan dalam pembelajaran satu semester.

\section{Siklus VI}

Siklus VI pada dilaksanaan pada pertemuan XIV, XV, XVI tanggal, 21, 28 Mei, dan 4 Juni 2018. Pada siklus VI, kegiatan yang dilakukan meliputi:

\section{Rencana Tindakan:}

a. Dosen menyiapkan materi pembelajaran . b. Dosen menyiapkan tesk bacaan.

c. Dosen menyusun bahan untuk latihan.

d. Dosen menyiapkan stategi pembelajaran yang relevan

e. Dosen menyediakan waktu untuk mahasiwa presentasi di kelas.

f. Dosen menyiapkan alat untuk pengamatan Adapun objek mahasiswa adalah keaktifan mahasiswa, keberanian tampil di kelas, kemampuan vocal. Adapun objek dosen adalah strategi penyampaian, bentuk tugas.

\section{Pelaksanaan Tindakan}

Pada siklus ke VI, pembelajaran memperkuat kemampuan vocal dengan mengakaitkan dengan materiyang sudah disusun selama satu semester. Metode pembelajaran dengan ceramah dan memberi kesempatan mahasiswa untuk berani berbicara untuk mengasah kemampuan vokalnya. Pelaksanaan tindakan, meliputi: setelah dosen menjelaskan materi, dengan urutan sebagai berikut.

a. Dosen menjelaskan ciri-ciri kalimat majemuk bertingkat atau complex sentence

b. Dosen menjelaskan cara mengenali subordinating conjunction dalam complex sentence

\section{Pengamatan.}

Pengamatan dilakukan oleh dosen pengampu. Sasaran yang diamati:

a. Jumlah mahasiswa yang hadir di kelas b. Jumlah mahasiswa yang berani tampil di kelas

c. Kemampuan vocal bicara mahasasiswa

Berdasarkan pengamatan pada siklus VI ada peningkatan hasil yang signifikan sebagaian besar mahasiswa sudah berani untuk tampil di depan kelas. Kemampuan vocal menjadi nilai lebih karena tujuan dari pembelajaran ini juga meningkatkan ketrampilan mahasiswa untuk dapat berkomunikasi menggunakan Bahasa Inggris. 


\section{Refleksi}

Tahapan pada proses pembelajaran siklus VI ini kemampuan vocal mahasiswa menjadi nilai yang lebih untuk menambah kemampuan vocal mahasiswa. Kemampuan vocal dapat membantu keberhasilan komunikasi dengan menggunakan Bahasa Inggris. Bahasa Inggris menjadi Bahasa komunikasi internasional.

Berdasarkan pengamatan metode pembelajaran yang dilakukan oleh dosen masih perlu ditingkatkan untuk memperoleh hasil yang lebih optimal.Meski ada beberapa kendala dalam poses pembelajaran di kelas. Kelas yang besar menjadi salah satu kendala pembelajaran menjadi kurang optimal.

Berikut ini hasil nilai mahasiswa Desain Interior yang mengambil matakuliah Bahasa Inggris.

\begin{tabular}{|c|c|c|c|c|c|}
\hline No. & NIM & Nama Mahasiswa & Hadir & Nilai & Huruf \\
\hline 1 & 18150101 & Adi Suwito & 12 & 3 & B \\
\hline 2 & 18150102 & Ahmad Nur Saifudin & 13 & 3,5 & $\mathrm{~B}+$ \\
\hline 3 & 18150103 & Dimas Agung Wicaksann & 13 & 3,5 & $\mathrm{~B}+$ \\
\hline 4 & 18150104 & Dirgantara Tampan Putra & 13 & 3,5 & $B+$ \\
\hline 5 & 18150105 & Diva Primarini & 12 & 3,5 & $\mathrm{~B}+$ \\
\hline 6 & 18150106 & Gitakara Syamsu Daradha & 12 & 3 & $B$ \\
\hline 7 & 18150107 & Haifa Ummul Nafisah & 15 & 3 & $B$ \\
\hline 8 & 18150108 & Hakiim Cahya Nugraho & 12 & 3 & B \\
\hline g & 18150109 & Fakhrizaki Cahya Permata & 15 & 3 & $B$ \\
\hline 10 & 18150110 & Juhanik Nuraisa & 14 & 3 & B \\
\hline$\|$ & 181501|| & Muhammad Ahsanu & 13 & 3 & B \\
\hline 12 & 18150112 & Muhammad Raga Septiana & 14 & 2,5 & $\lceil+$ \\
\hline 13 & |81501|3 & Farhan Ridha Amali & 14 & 3 & $B$ \\
\hline 14 & 18150114 & Rhei Nida Salsabilla & 15 & 3,5 & $\mathrm{~B}+$ \\
\hline 15 & 18150115 & Rizky Hikmatul Maulidia & 15 & 3,5 & $\mathrm{~B}+$ \\
\hline 旧 & |81501||6 & Vernanda Juni Hariyanta & 14 & 3 & B \\
\hline 17 & 18150118 & Virda Rodhiyah & 14 & 3,5 & B+ \\
\hline 18 & 18150119 & Lidwina Enggar & 13 & 3 & $B$ \\
\hline 19 & 18150120 & Zaim Mahasin Atsir & 14 & 3 & B \\
\hline 20 & 18150121 & Suci Safiyamanda & 13 & 3,5 & $\mathrm{~B}+$ \\
\hline 21 & 18150122 & Neili Delila Fairalsa & 15 & 3 & B \\
\hline 22 & 18150123 & Rumba Djati Mahendra & 15 & 3,5 & $\mathrm{~B}+$ \\
\hline 23 & 18150124 & Tesalonika Vagilia & 15 & 3,5 & $\mathrm{~B}+$ \\
\hline 24 & 18150126 & Aldi Taryanto & 15 & 3 & $B$ \\
\hline 25 & 18150127 & Aji Saputra & 15 & 3,5 & $\mathrm{~B}+$ \\
\hline 26 & 18150128 & Sapto Nugraho & 15 & 3 & B \\
\hline 27 & 18150129 & Ragil Amiruddin Saleh & 15 & 3 & $B$ \\
\hline
\end{tabular}

\begin{tabular}{|c|c|c|c|c|c|}
\hline 28 & 18150130 & Machamad Firman & 12 & 3 & $B$ \\
\hline 29 & $|8| 50131$ & Ilham Giri Suseno & 14 & 3 & $B$ \\
\hline 30 & 18150132 & Aysa Kantun Wijayanti & 15 & 3 & $B$ \\
\hline 31 & 18150133 & Muhammad Hasbi & 12 & 2,5 & {$[+$} \\
\hline 32 & 18150134 & Adinda Amartya Sukma & 13 & 3 & B \\
\hline 33 & 18150135 & Muhamad Fadilah Fatah & 14 & 3 & $B$ \\
\hline 34 & 18150136 & Bagas Leonanda & 14 & 3 & B \\
\hline 35 & 18150137 & Dewi Maisarah & 13 & 3 & $B$ \\
\hline 36 & 18150138 & Karim Abdul Jabar & 13 & 3 & $B$ \\
\hline 37 & 18150139 & Dimas Rachmat Bhirawa & 12 & 3 & $B$ \\
\hline 38 & 18150140 & Zahidatul Asyiyah & 15 & 3 & $B$ \\
\hline 39 & 18150141 & Arby Prasetio & 15 & 3 & $B$ \\
\hline 40 & 18150142 & Denisa Afia Gitanyali & 12 & 3,5 & $\mathrm{~B}+$ \\
\hline 41 & 18150143 & Virgiawan Listanto & 12 & 3 & B \\
\hline 42 & 18150144 & Dimas Pramudita & 7 & 3 & B \\
\hline 43 & 18150145 & Yogi Hanafi & 15 & 3 & $B$ \\
\hline 44 & 18150146 & Adilia Nadiartha Sekar & 15 & 3,5 & $\mathrm{~B}+$ \\
\hline 45 & 18150147 & Diva Raisa Aulia Azahra & 15 & 3,5 & $\mathrm{~B}^{+}$ \\
\hline 46 & 18150148 & Ignatia Dwi Intan & 15 & 3,5 & $\mathrm{~B}^{+}$ \\
\hline 47 & 18150149 & Muhammad Aji Saputro & 14 & 3 & $B$ \\
\hline 48 & 18150150 & Alif Latifah Hani & 14 & 3 & $B$ \\
\hline 49 & 18150151 & Sry Anugrah Sipayung & 13 & 3 & $B$ \\
\hline 50 & 18150152 & Yohana Cristiyanta & 13 & 3 & $B$ \\
\hline 51 & 18150154 & Rijal Ramadhoni & 12 & 3 & $B$ \\
\hline 52 & 18150155 & Edy Sudrajat & 15 & 3 & $B$ \\
\hline 53 & 18150157 & Aditya Dwi Perwira & 15 & 3 & $B$ \\
\hline 54 & 18150158 & Septy Nurlia Vinnasari & 15 & 3 & $B$ \\
\hline 55 & 18150159 & Nanda Kurniawan & 0 & ए & $E$ \\
\hline 56 & 18150160 & Ghinaa Kaamalia Amanda & 15 & 3 & $B$ \\
\hline 57 & |8150161 & Dira Sekar Ningrum & 15 & 3 & $B$ \\
\hline 58 & 18150162 & Albertus Agung Paskah & 12 & 3 & B \\
\hline 59 & 18150164 & Taksulanapurusa & 15 & 3,5 & $B+$ \\
\hline 60 & 18150165 & Vincentius Bhima & 12 & 3 & $B$ \\
\hline 61 & 18150166 & Raden Raro Ajeng Dira & 15 & 3,5 & $\mathrm{~B}^{+}$ \\
\hline 62 & 18150167 & Mahza Dewangga Brata & 13 & 3 & B \\
\hline 63 & 18150168 & Ratih Raka Siwi & 14 & 2,5 & ¿+ \\
\hline 64 & 18150169 & Aghnia Khosyiah Azmi & 12 & 3 & $B$ \\
\hline 65 & 18150170 & Muhammad & 12 & 3 & B \\
\hline 66 & 18150171 & Retno Pantini & 13 & 3 & $B$ \\
\hline 67 & 18150172 & Luthfiyah Shalihatul Amali & 14 & 3 & $B$ \\
\hline 68 & 18150173 & Muhammad Syahrul Irfan & 12 & 3 & $B$ \\
\hline 69 & 18150174 & Nugraho Hari Cahyono & 12 & 3 & $B$ \\
\hline 70 & 18150175 & Maulidya Noor Lathiefa & 14 & 3 & $B$ \\
\hline 71 & 18150177 & Arif Dwi Rahman & 13 & 3 & $B$ \\
\hline 72 & 18150178 & Difani Aulia Restanti & 14 & 3 & $B$ \\
\hline 73 & 18150179 & Naufal Helmy Al-fauzi & 12 & 3 & $B$ \\
\hline 74 & 18150181 & Fridalino Ati & 14 & 3 & $B$ \\
\hline
\end{tabular}




\section{KESIMPULAN}

Beberapa problem saat terjadinya pembelajaran Bahasa Inggris di kelas antara lain:

1. Kelas untuk teori harusnya dibuat lebih ideal misalnya satu kelas diisi dengan 40 mahasiswa. Di kelas Prodi Desain Interior di isi dengan 74 mahasiswa artinya kelas ini terlalu besar sehingga dosen harus bekerja keras untuk mengkondisikan kelas besar. Sehingga kemungkinan kurang bisa maksimal untuk melakukan pengamatan secara komprehensif.

2. Materi Bahasa Inggris di peroleh mahasiswa hanya satu kali dengan bobot SKS 3 . Untuk memenuhi target agar mahasiswa bisa berkomunikasi secara ideal dan baik kemungkinan kurang bisa tercapai $100 \%$. Menginggat kemampuan untuk menguasai bahasa bukanlah hal yang instan akan tetapi melalui latihan intens selama beberapa bulan. Akan tetapi melihat kemampuan belajar mahasiswa Desain Interior masih tergolong baik.

3. Ada beberapa kelemahan mahasiswa terkait dengan materi pembelajaran yang diberikan belum sepenuhnya dipahami sebelum dosen menjelaskan materi.

4. Rata-rata mahasiswa masih mengandalkan sumber materi dari dosennya. Paradigma seperti harus diubah untuk bisa mengupdate materi dari sumber lainnya.

\section{DAFTAR PUSTAKA}

Bettencourt, A. 1989. What is Constructivism and Why are They all. Talking about it? Michigan State University.

Kemis, S. And McTaggert, R. 1998. The Action Research Planner. Deakin University.

Paulina Pannen, dkk. 2005. Konstruktivisme dalam Pembelajaran. Jakarta: Pusat Antar Universitas untuk Peningkatan dan Pengembangan Aktivitas Instruksional Direktorat Jendrak Pendidikan Tinggi.

Raka J.T, Kardiawarman, dan Trisno, H (1998). Konsep Dasar Penelitian Tindakan Kelas (Classroom Action Research). Jakarta: Proyek Pengembangan Guru Sekolah Menengah Depdikbud.

Rosmiati, Ana. 2017. Problem Based Introduction sebagai Model Pembelajaran Matakuliah Seminar di Program studi DKV FSRD ISI Surakarta. PTK. 